Article

\title{
Use of a Simple GIS-Based Model in Mapping the Atmospheric Concentration of $\gamma-\mathrm{HCH}$ in Europe
}

\section{Pilar Vizcaino * and Alberto Pistocchi}

Institute for Environment and Sustainability, Joint Research Centre, European Commission, 21027 Ispra (VA), Italy; E-Mail: alberto.pistocchi@jrc.ec.europa.eu

* Author to whom correspondence should be addressed;

E-Mail: pilar.vizcaino-martinez@ext.jrc.ec.europa.eu; Tel.: +39-388-173-6418.

External Editor: Javier Castro Jiménez

Received: 20 March 2014; in revised form: 22 July 2014 / Accepted: 19 August 2014 /

Published: 15 October 2014

\begin{abstract}
The state-of-the-art of atmospheric contaminant transport modeling provides accurate estimation of chemical concentrations. However, existing complex models, sophisticated in terms of process description and potentially highly accurate, may entail expensive setups and require very detailed input data. In contexts where detailed predictions are not needed (e.g., for regulatory risk assessment or life cycle impact assessment of chemicals), simple models allowing quick evaluation of contaminants may be preferable. The goal of this paper is to illustrate and critically discuss the use of a simple equation proposed by Pistocchi and Galmarini (2010), which can be implemented through basic GIS functions, to predict atmospheric concentrations of lindane $(\gamma-\mathrm{HCH})$ in Europe from both local and remote sources. Concentrations were computed for 1995 and 2005 assuming different modes of use of lindane and consequently different spatial patterns of emissions. Results were compared with those from the well-established MSCE-POP model (2005) developed within EMEP (European Monitoring and Evaluation Programme), and with available monitoring data, showing acceptable correspondence in terms of the orders of magnitude and spatial distribution of concentrations, especially when the background effect of emissions from extracontinental sources, estimated using the same equation, is added to European emissions.
\end{abstract}

Keywords: atmospheric pollution modeling; lindane; simple equation; GIS 


\section{Introduction}

Atmospheric contaminant transport modeling has reached in the past few decades a high level of sophistication, which enables detailed and accurate simulation of a number of physico-chemical processes (e.g., [1]). However, the use of sophisticated models per se does not ensure accurately predicting the distribution in the environment of contaminants, when emissions are poorly known. Moreover, sophisticated models often include a description of processes at a very fine level, while orders of magnitude of predicted environmental concentrations (PECs) of contaminants, often sufficient for screening-level assessment purposes, may be captured using far simpler approaches. In such contexts as regulatory environmental or human health risk assessment and life cycle impact assessment, the atmospheric fate of pollutants is sometimes studied using simple box models (e.g., [2-4]), which provide a quick and robust estimate of orders of magnitude of PECs. However, box models only provide average PECs over the region where emission takes place and do not account for upwind and downwind effects; therefore, they can neither be used to predict the spatial distribution of environmental concentrations from a specific source, nor the cumulative concentration at a given location arising from a spatial distribution of emissions. In order to preserve the simplicity of application of box models, yet taking into account the spatial variability of emissions and concentrations away from emission sites, research promoted by the European chemical industry has brought the development of a simple, spatially-explicit model named ADEPT [4]. This model enables predicting annual average concentrations from atmospheric emissions in Europe, assigned as totals from individual European countries, assumed to be constant along the year and proportional to population density within each country. The model was derived with reference to the year 1997, assumed as a representative year. The ADEPT model is embedded in a spatially-explicit multimedia fate and transport model developed at the European scale, also referred to as the MAPPE model ([5-7]), using geographic information system (GIS) operations and combining data of emissions, physico-chemical properties and seasonally-varying environmental and climate parameters, as described in [8]. Pistocchi and Galmarini [9] conducted an evaluation of the model, which highlighted that the ADEPT model provides reasonable estimates of atmospheric concentrations of conventional chemicals (sulfur and nitrogen oxides), by capturing the orders of magnitude of observed concentrations and, to some extent, their spatial trends over Europe. They also showed that the ADEPT model is consistent with box models used in regulatory contexts. The drawback of ADEPT is that it reflects a specific emission pattern, i.e., the distribution of population. However, the authors point out that the ADEPT model may be approximated with an extremely simple equation, in turn applicable to a generic distribution of sources of emissions, hence useful when the assumption of emissions proportional to population density cannot be applied.

The aim of this paper is to demonstrate the feasibility of modeling the spatial distribution of atmospheric concentrations of lindane $(\gamma-\mathrm{HCH})$ in Europe, using the simple equation proposed by Pistocchi and Galmarini [9].

Lindane is a chemical that was used worldwide during the past few decades as an insecticide [10]. Currently, it is included in the list of persistent organic pollutants (POPs) under the Stockholm Convention [11], and its use in Europe is severely restricted [12,13]. Due to its high volatility and atmospheric persistence, $\gamma-\mathrm{HCH}$ is likely to undergo long-range atmospheric transport. This chemical 
was selected as a case study because of the availability of relatively detailed global usage estimates [14-16], as well as extensive and long-term environmental monitoring data in different media and, specifically, in the atmosphere [17-31]. Finally, the restriction of $\gamma-\mathrm{HCH}$ in Europe since the mid-1990s [32] has affected both the modes of release into the environment and the total amounts emitted. All of these features make $\gamma-\mathrm{HCH}$ an interesting target chemical for the test of fate models.

In agricultural use, lindane was predominantly applied to soil [33], but its relative volatility and atmospheric stability have led to long-range transport in the atmosphere [34-37]. Furthermore, atmospheric concentrations in Europe have been estimated to originate to a certain extent from extracontinental sources [14-16]. Due to the agriculture-related pattern of emissions and the importance of extracontinental sources, a readily-available model, such as ADEPT, cannot be applied in this case.

In this contribution, we demonstrate the use of the simple equation of Pistocchi and Galmarini [9] as a surrogate for, and a practical alternative to, more complex atmospheric transport models under certain conditions. The proposed approach is evaluated against both monitored concentrations and the results of the well-established MSCE-POP model [1], in order to derive guidance on the limits of the applicability of such a simple method.

\section{Material and Methods}

Pistocchi and Galmarini [9] show that the spatial patterns of the annual average concentration of a conservative chemical from a given emission in the atmosphere can be represented, for screening purposes, using an extremely simple equation comparable to the one of box models as:

$$
C=\alpha \frac{E}{\mathrm{u} \mathrm{H} \mathrm{d}^{\beta}}
$$

where $\mathrm{E}[\mathrm{M}] \cdot[\mathrm{T}]^{-1}$ is the emission rate, $\alpha[\mathrm{L}]^{\beta-1}$ is a proportionality constant, $\mathrm{H}[\mathrm{L}]$ is a representative atmospheric mixing height, $\mathrm{u}[\mathrm{L}] \cdot\left[\mathrm{T}^{-1}\right]$ is a representative wind speed and $\mathrm{d}[\mathrm{L}]$ is the distance from the source of emission, while $\beta$ is an empirical exponent. This equation is applicable at some distance from the source as, for $d=0, C$ would go to infinity. For Europe, Pistocchi and Galmarini [9] show that $\beta=1.3$, $\alpha=1 \mathrm{~m}^{\beta-1}, \mathrm{u}=3 \mathrm{~m} \cdot \mathrm{s}^{-1}$ and $\mathrm{H}=1000 \mathrm{~m}$ allow reproducing correctly the spatial trends of the ADEPT model with acceptable accuracy. When dealing with a non-conservative chemical having decay rate $K$, the equation should be modified as:

$$
C^{\prime}=\alpha \frac{E}{\mathrm{u} \mathrm{H} \mathrm{d}^{\beta}} e^{-K \tau}
$$

where $\tau$ is "time of travel" or time necessary to reach distance $d$ from the source; Pistocchi and Galmarini also show a reasonable proxy for $\tau$ is the ratio of $\mathrm{d}$ to $\mathrm{u}$. However, as the dominant removal mechanism of contaminants from the atmosphere is in most cases atmospheric dilution [17], the approximation of conservative chemicals is often reasonably safe.

Equation (1) is similar to the box model equation frequently used for predicting environmental concentrations as average atmospheric concentrations over a region where emission takes place. The difference with box models is in the denominator, where the variable distance term $\mathrm{d}^{\beta}$ replaces a fixed cross-wind width, making concentrations dependent on the distance from the source. Equation (1) or Equation (2) cannot be solved for $\mathrm{d}=0$, i.e., at the source, and, in general, are not meant to represent 
concentrations in the "near field" of emissions, where a box model should be applied instead. As a complement to the box model, which predicts regional average concentrations due to a local emission, Equation (1) or Equation (2) allow screening-level prediction of regional concentrations due to a remote emission. Distance $\mathrm{d}$ is meant as a Euclidean (isotropic) distance, which does not account for the directional transport of contaminants. As such, the model predicts an order of magnitude of concentrations from remote emissions, under the assumption that a chemical may actually reach a given region of interest. Therefore, the model should be only applied in regions where atmospheric transport may actually occur in all directions or any way when it is expected that transport between two regions may actually occur. In any other case, of course, models of adequate complexity should be used to describe atmospheric contaminant transport.

Sometimes, remote emissions are not known, but we know concentrations in one region. In particular, if we consider a grid of points with regular spacing $\mathrm{X}$, the concentration resulting at a generic grid cell at distance $\mathrm{d}$ from a cell with known concentration $\mathrm{C}_{0}$ can be computed as:

$$
C=C_{0}\left(\frac{0.5 \mathrm{X}}{d}\right)^{\beta}
$$

If we have several cells with known concentration, their effects must be superimposed, and Equation (3) becomes, in practice, an inverse distance weighting interpolation.

If instead of a single emission at one cell we consider a map of emissions $E(x, y)$ potentially with a non-zero value of emission at each cell of size $X$, the resulting atmospheric concentration at the generic point $(\mathrm{x}, \mathrm{y})$ could be consequently calculated by superimposing the effects. The final equation could be expressed as the sum of the concentration from the local emission $\mathrm{E}(\mathrm{x}, \mathrm{y})$ within the cell (where distance would be equal to $\mathrm{X} / 2$ ), plus the concentration from all emissions at locations different from (x, y), each evaluated with Equation (1). This can be expressed in mathematical notation as:

$$
C(x, y)=\frac{E_{(x, y)}}{\mathrm{uH}\left(\frac{\mathrm{X}}{2}\right)^{\beta}}+\int_{\Omega(x, y)} \frac{E_{(\xi, \eta)}}{\mathrm{uHd}_{(\xi, \eta)}^{\beta}} d \xi d \eta
$$

$\Omega(\mathrm{x}, \mathrm{y})$ being the whole computational domain excluding point $(\mathrm{x}, \mathrm{y})$. For non-conservative chemicals, an equivalent formulation reflecting Equation (2) in place of Equation (1) is:

$$
C^{\prime}(x, y)=\frac{E_{(x, y)}}{\mathrm{uH}\left(\frac{\mathrm{X}}{2}\right)^{\beta}}+\int_{\Omega(x, y)} \frac{E_{(\xi, \eta)}}{\mathrm{u} \mathrm{H} \mathrm{d}_{(\xi, \eta)}^{\beta}} \exp \left(-K \frac{d_{(\xi, \eta)}}{u}\right) d \xi d \eta
$$

The estimate does not account for the spatial variability of decay rates, assumed as a constant value $K$, and dilution, which is reflected by the constant terms, $u, H$ and $\beta$.

The equation can be easily computed for each cell of a grid to obtain a spatial distribution of concentrations, once a representative decay rate $K$ and a map $\mathrm{E}(\mathrm{x}, \mathrm{y})$ is provided, using standard GIS functionalities. A GIS procedure to compute Equation (4) or Equation (5) entails:

(1) a map algebra calculation of the first term of Equation (4) or Equation (5), which is just the emission map divided by a constant denominator; 
(2) a calculation of one Euclidean distance map for each cell of the grid, representing the spatially-varying term $\mathrm{d}$ in the integrand of the second term; if we have a grid of $\mathrm{n}$ rows and $\mathrm{m}$ columns, this entails a calculation of $\mathrm{n} \times \mathrm{m}$ distance maps;

(3) a map algebra calculation of the expression of this integrand, which is a combination of the map of distance $d$, multiplied by the emission value corresponding to grid cell, where $d=0$; this entails potentially $\mathrm{n} \times \mathrm{m}$ calculations of the integrand;

(4) a summation of the $n \times m$ integrand maps of the previous step;

(5) a sum of the result with the term computed in the first step.

The implementation of such a procedure requires simple coding of the iteration of the above Steps 3 and 4 in a GIS environment, such as, e.g., the Python interface of ESRI ArcGIS 10.x.

The above described method was applied to model lindane atmospheric concentration in Europe in 1995 and 2005, using the same grid spacing for Europe as adopted in the original ADEPT model, i.e., $0.25^{\circ} \times 0.25^{\circ}$ and physico-chemical properties defined in [37].

Emissions to the atmosphere were assigned to each grid cell on the basis of national totals per year provided by EMEP [38] and reported in [39,40], which represent the most accurate data available, as they consist of official emissions to the atmosphere reported by countries, integrated by expert estimates(as discussed in [33]), and are summarized in Table 1.

We considered year 1995 as representative of the emissions before restrictions. In this year, $\gamma-\mathrm{HCH}$ was still mainly used in agriculture as a pesticide. Emissions to the different media were calculated from the data of emissions to the atmosphere (Table 1), considered as national totals. Emissions were assumed to follow the same mode of application as the one followed in the POPCYCLING-Baltic model [41], i.e., $17.5 \%$ of the total release of $\gamma-\mathrm{HCH}$ as applied to the atmosphere, $80 \%$ to soil and $2.5 \%$ to continental freshwater. In addition to atmospheric emissions, we used the MAPPE model in the setup described in Vizcaino and Pistocchi [42] to derive volatilization fluxes of lindane emitted to soil. The procedure to compute volatilization fluxes from emissions is presented in Pistocchi [43]. This calculation, however, showed that volatilization fluxes are two to three orders of magnitude lower than direct emissions to the atmosphere and can therefore be neglected for the present application.

Atmospheric emissions were distributed within agricultural areas proportionally to the intensity of agricultural usage of the area. The emission at a generic cell of a regular grid, E(x,y), was computed as the total emission E of the country (values from Table 1) to which the location belongs, E, multiplied by the fraction of total agricultural land of the country in that cell, i.e.,

$$
E(x, y)=E \frac{A(x, y)}{\sum_{(x, y) \in\{\text { country }\}} A(x, y)}
$$

$\mathrm{A}(\mathrm{x}, \mathrm{y})$ being the percentage of area of the cell that is agricultural land.

For the year 2005, when $\gamma$-HCH was already banned or restricted to mainly non-agricultural uses, we excluded applications directly to soil, and consequently, total emissions coincide with atmospheric ones with values corresponding to the ones presented in Table 1. As the uses were mainly non-agricultural, we assumed them to follow population patterns, and in order to obtain a gridded estimate of emissions, we used Equation (6), replacing agricultural area with total population per grid cell and per country. 
Table 1. Atmospheric emissions per country for 1995 and 2005 used for the computations.

\begin{tabular}{|c|c|c|}
\hline EMEP Grid Country & Atm. Emissions in 1995 (Tons) & Atm. Emissions in 2005 (Tons) \\
\hline Albania & 0.463 & 0.123 \\
\hline Austria & 8.1 & 0 \\
\hline Belgium & 0.165 & 0.168 \\
\hline Bosnia and Herzegovina & 0.515 & 0.115 \\
\hline Bulgaria & 0 & 0 \\
\hline Croatia & 12 & 3.2 \\
\hline Cyprus & 0 & 0 \\
\hline Czech Republic & 0.319 & 0 \\
\hline Denmark & 0 & 0 \\
\hline Estonia & 0.005 & 0 \\
\hline Finland & 0 & 0 \\
\hline France & 560 & 40 \\
\hline Germany & 13 & 0 \\
\hline Greece & 5.9 & 2.4 \\
\hline Hungary & 1.7 & 0 \\
\hline Ireland & 2.2 & 0 \\
\hline Italy & 2.2 & 2.2 \\
\hline Latvia & 0.002 & 0 \\
\hline Lithuania & 0.003 & 0 \\
\hline Luxembourg & 0.151 & 0 \\
\hline Netherlands & 0 & 0 \\
\hline Norway & 0 & 0 \\
\hline Poland & 0.283 & 0 \\
\hline Portugal & 11 & 7.7 \\
\hline Romania & 2.3 & 1.1 \\
\hline Serbia \& Montenegro & 1.5 & 0.51 \\
\hline Slovakia & 0 & 0 \\
\hline Slovenia & 0 & 0 \\
\hline Spain & 9.5 & 10 \\
\hline Sweden & 0 & 0 \\
\hline Switzerland & 0 & 0 \\
\hline The FYR of Macedonia & 0.063 & 0.087 \\
\hline United Kingdom & 59 & 13 \\
\hline Europe, $\mathrm{t}$ & 845 & 80.6 \\
\hline
\end{tabular}

Estimations based on official data on use of tech. $\mathrm{HCH}$ and lindane Official data on $\mathrm{HCH}$ emissions

Expert estimates (Pacyna et al. [33])

Estimations based on official information

\section{Results and Discussion}

Figure 1 presents the map of estimated concentrations of $\gamma-\mathrm{HCH}$ in the atmosphere for 1995 and 2005 computed with Equation (5) as explained above. It can be observed that concentrations follow 
clearly national emissions, with France having the highest emission rate in Europe. As expected, higher values of concentrations are linked, within every country, to agricultural areas (in 1995) and to population density (in 2005). In the year 2005, when emissions follow population density, lindane is applied to more limited areas than in 1995, when it is used in agriculture. Average predicted concentrations in 2005 are approximately a factor of 10 lower than in 1995, reflecting the same difference in emissions, and the spatial pattern highlights a more homogeneous distribution in 1995, while, as a consequence of assuming emissions related to population, in 2005, the distribution has a spotty appearance with peaks around large conurbations.

Figure 1. Modeled values of concentrations of $\gamma-\mathrm{HCH}$ expressed as concentrations $\left(\mathrm{ng} / \mathrm{m}^{3}\right)$ in atmosphere in 1995 (left) and 2005 (right) using Equation (5) (top) and the EMEP MSCE-persistent organic pollutant (POP) model (bottom). Concentrations from the MSCE-POP model were provided by A. Gusev, [44] and reflect model setups and assumptions also described in [45].

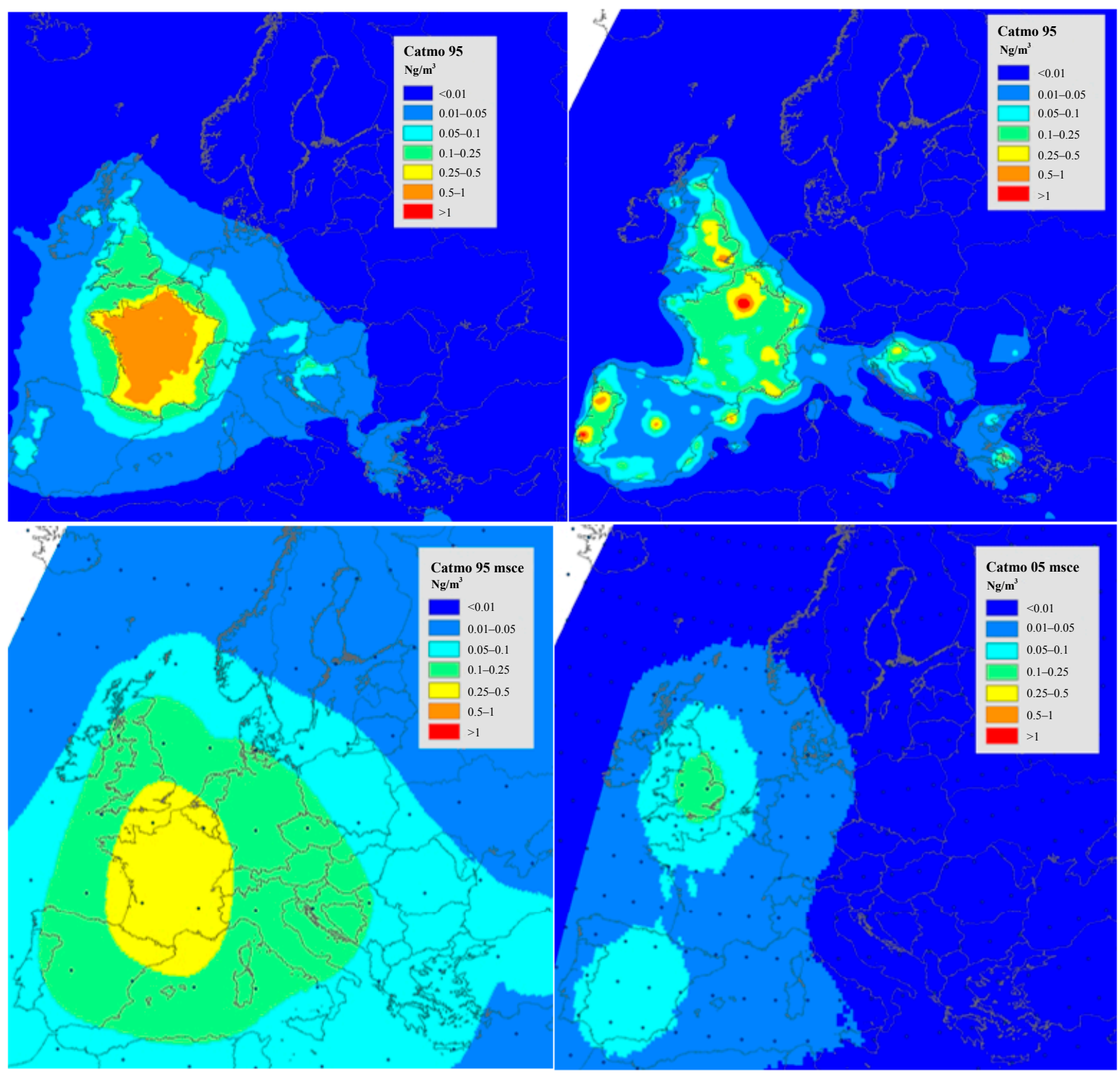


It is worth stressing that the assumption of a certain emission pattern has effects on the frequency distribution of predicted concentrations, even when the national totals do not change. If we repeat the exercise, assuming, for instance, emissions in 1995 to follow population instead of agricultural intensity, the histogram of the map of predicted concentrations would change as shown in Figure 2. When assuming emissions proportional to population density, more evident hotspots appear nearby the most densely populated areas, whereas in low-population areas, concentrations are lower. On the contrary, using agricultural area as an emission pattern, concentrations are more uniformly distributed in space with a higher frequency of middle-lower values and a lower frequency of middle-higher values.

Figure 2. Histogram of $\gamma$-HCH concentration $\left(\mu \mathrm{g} / \mathrm{m}^{3}\right)$ computed with Equation (5) for the year 1995 with the distribution of emissions according to agriculture or to population density.

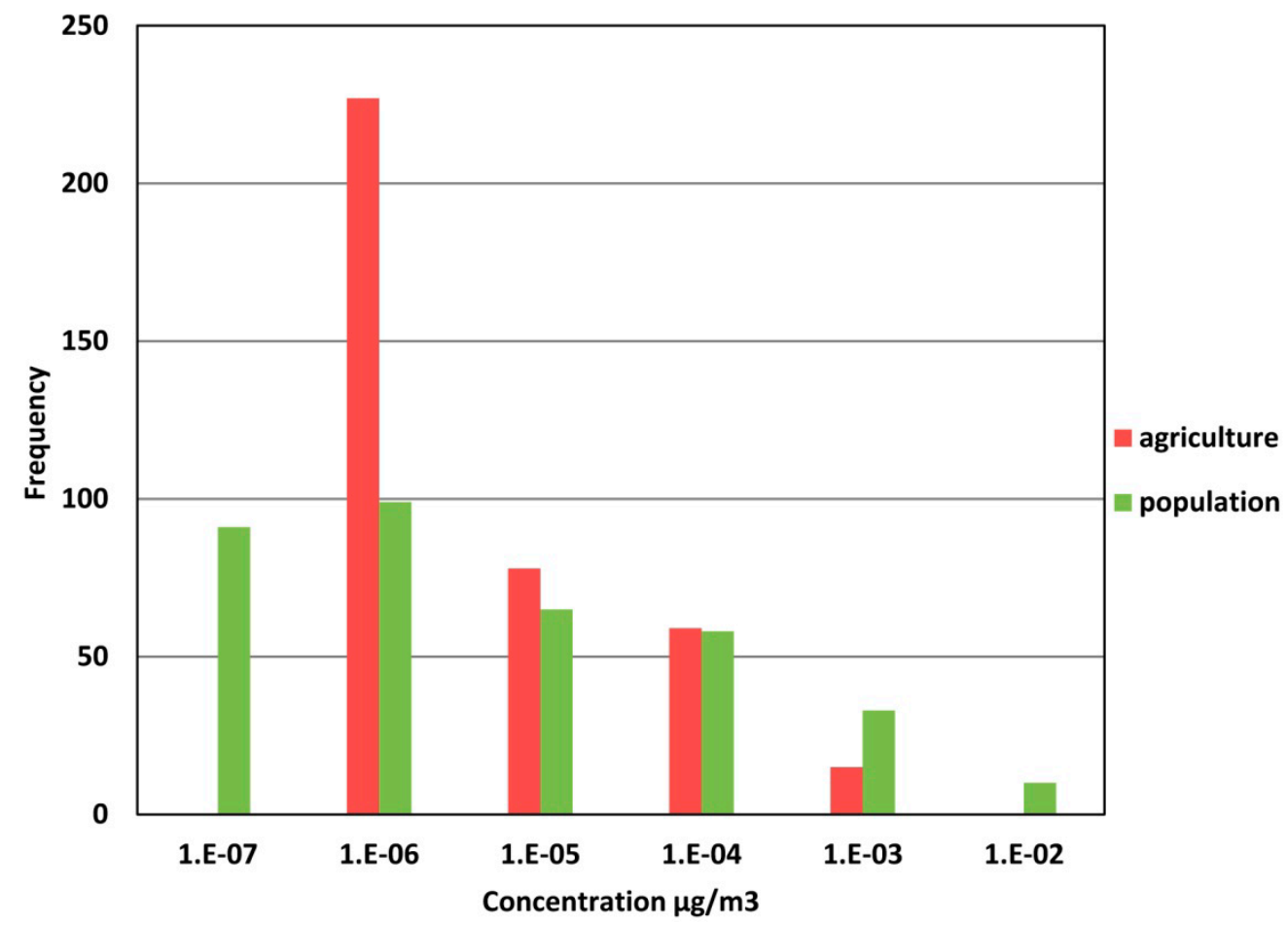

Lindane has been studied rather broadly, and a number of data can be retrieved from the literature. However, most of the available data refer to a limited number of monitoring stations, such as the ones participating in the EMEP program (www.emep.int) and providing data online; these enable a satisfactory evaluation of orders of magnitude and temporal trends of atmospheric concentrations, but not so much of spatial patterns. Some monitoring campaigns were developed with passive samplers [21,29]. Other monitored atmospheric concentrations reported in the literature [22,24-31] are not sufficiently homogeneous and comparable to support any assessment of spatial distributions.

Therefore, as a surrogate for a monitored spatial distribution of lindane atmospheric concentration, the well-established MSCE-POP model [1] was used as a benchmark for the evaluation of our simple model, as is common practice in other similar circumstances (e.g., [5,42]). The MSCE-POP model provides the results of concentrations within a hemispheric grid of $2.5^{\circ} \times 2.5^{\circ}$ spatial resolution (also shown in Figure 1) and describes gaseous exchange between the atmosphere and the underlying surface, including soil, seawater, vegetation, sea ice and snow, as well as the main processes in these 
media. As our model has a resolution of 1-km cell size, our results were averaged within the cells of the hemispheric MSCE-POP grid over Europe for comparison. Furthermore, standard deviations within each cell were extracted, which provided the range of variation of concentrations.

Figure 3. Comparison between predicted and monitored 5\%-95\% ranges of concentrations for 1995 (above) and 2005 (below). Monitored concentrations are obtained from monitoring campaigns (Kylin and Sjödin [24], Wenzel et al. [25]) and EMEP stations (www.emep.int).

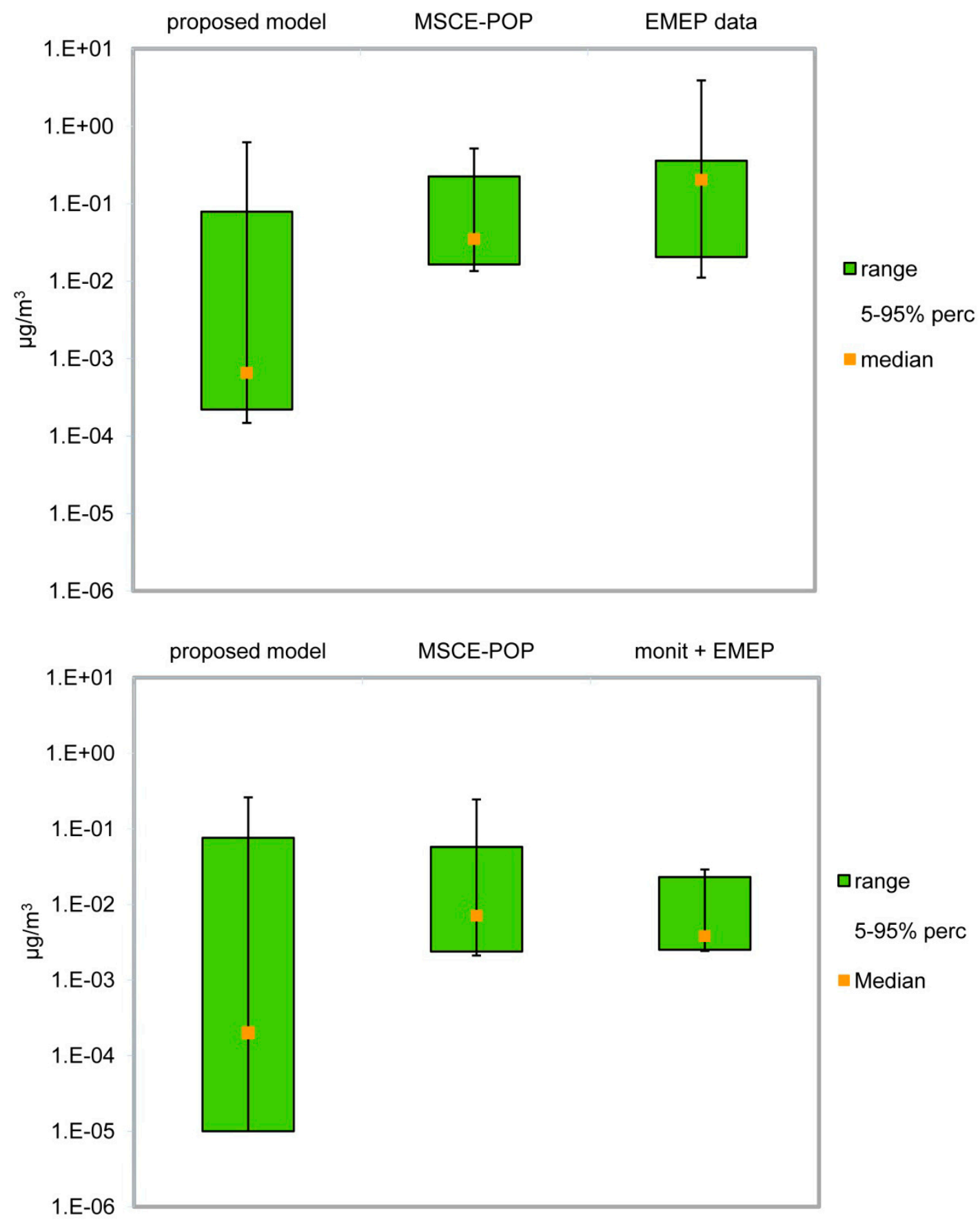

In Figure 3, we compare predicted concentrations with monitored values for the years 1995 and 2005; although the upper extremes tend to be fairly similar, concentrations predicted with Equation (5) are apparently lower than observations in both years. The same figure shows also the range of concentrations predicted through the MSCE-POP model, chosen as a benchmark. In this case, concentrations are correctly 
predicted in the whole range, supporting the reliability of this model as a reference to evaluate spatial distributions obtained from Equation (5).

Figure 4 illustrates the spatial correspondence between the two models; the scatter diagram plots the value predicted by MSCE-POP versus the average of values predicted for the cells on which Equation (5) is computed around each MSCE-POP grid cell; error bars are given by the standard deviation of the predictions of Equation (5), within each MSCE-POP grid cell. It can be observed that Equation (5) is able to explain approximately $60 \%$ of the variance in 1995 and around 36\% in 2005 . The higher end of predicted concentrations is acceptably consistent between the two models. However, there is a clear trend to underestimate the lowest concentrations predicted with Equation (5) compared to those from the MSCE-POP model.

One possible reason for this discrepancy at lower concentrations might be the presence of background lindane advected from extra-European regions, which, on the contrary, is accounted for in the hemisphere MSCE-POP model.

Considering that the atmospheric residence time of $\gamma-\mathrm{HCH}$ ranges from five to 100 days (e.g., [30,41]) and using travel time as the ratio of the distance to a velocity of $3 \mathrm{~m} / \mathrm{s}$, as suggested by Pistocchi and Galmarini [9], it can be clearly understood that chemical transport from regions as far as thousands of kilometers away may partly reach Europe. In North America, although legislation controlling lindane was introduced in the early 2000s, at the time of the more recent model simulations, it was still used as a canola seed treatment [15]. Monitoring campaigns in 2004 still detected $\gamma-\mathrm{HCH}$ in air across all of North America $[15,20,46]$. By 2007, India still permitted the use of lindane for pharmaceutical uses and specific crops, and China was still producing lindane, although the use was banned within the country [47].

We may still use Equation (4) to compute background concentrations from extra-European sources. Let us denote with $\mathrm{C}_{\mathrm{bkg}}$ the concentration arising from an extra-continental emission of unknown intensity $\mathrm{E}^{*}$ at distance $\mathrm{X}_{\mathrm{bkg}}$ from where we want to compute concentration. If we are interested in an average background concentration in Europe due to an extracontinental source, a representative distance $\mathrm{X}_{\mathrm{bkg}}$ may be the distance from the centroid of the emission region to the centroid of Europe. $\mathrm{C}_{\mathrm{bkg}}$ is then:

$$
\mathrm{C}_{\mathrm{bkg}}=\frac{E^{*}}{u H X_{b k g}{ }^{\beta}}
$$

In the following Table 2, we report emissions from different extra-European regions along with a representative distance $X_{\mathrm{bkg}}$ from the centroid of each of them to the centroid of Europe and the correspondingly computed concentrations $C_{b k g}$ in 1995 and 2005. These concentrations are additive; therefore, their sum provides an estimate of the background in Europe. It should be noted that concentrations are estimated considering atmospheric transport as isotropic (distance $\mathrm{X}_{\mathrm{bkg}}$ is Euclidean and does not take into account dominant transport directions due to atmospheric circulation). The rational grounds for this assumption lie in the fact that we want to estimate merely a plausible order of magnitude of concentrations from emissions at a given source, as discussed in Pistocchi and Galmarini [9]. 
Table 2. Representative emissions of lindane as reported by $[32,48]$ and predicted background atmospheric concentrations $\left(\mathrm{pg} / \mathrm{m}^{3}\right)$.

\begin{tabular}{|c|c|c|c|c|c|}
\hline Source & $\begin{array}{c}\text { Representative Emission } \\
\text { (t/year), } 1995\end{array}$ & $\begin{array}{l}\text { Representative Emission } \\
\text { (t/year), } 2005\end{array}$ & $\begin{array}{l}\text { Representative } \\
\text { Distance (km) }\end{array}$ & $\begin{array}{l}\text { Conc. } 1995 \\
\left(\mathrm{pg} / \mathrm{m}^{3}\right)\end{array}$ & $\begin{array}{c}\text { Conc. } 2005 \\
\left(\mathrm{pg} / \mathrm{m}^{3}\right)\end{array}$ \\
\hline N. America & 700 & 200 & 9,500 & 6.28 & 1.79 \\
\hline China & 400 & 400 & 8,500 & 4.15 & 4.15 \\
\hline India & 600 & 200 & 6,500 & 8.82 & 2.94 \\
\hline
\end{tabular}

Figure 4. A comparison of the average concentrations in the atmosphere (in $\mathrm{ng} / \mathrm{m}^{3}$ ) in 1995 and 2005 derived from Equation (5) and the MSCE-POP model, respectively.

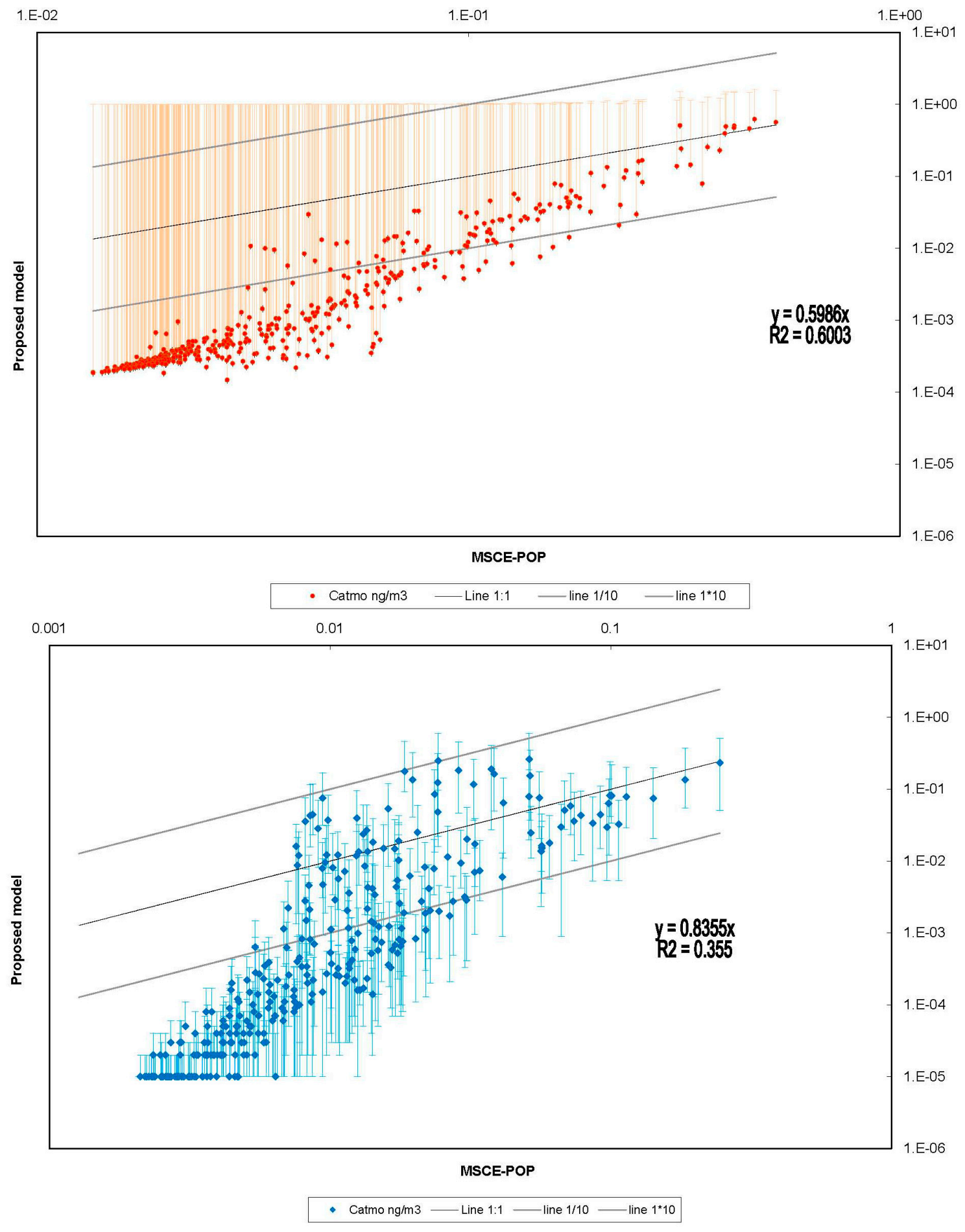


The calculations discussed above yield a background concentration of about $20 \mathrm{pg} / \mathrm{m}^{3}$ for 1995 and $10 \mathrm{pg} / \mathrm{m}^{3}$ for 2005 . When including this background, lower values of predicted atmospheric concentrations come closer to the MSCE-POP model estimates, while at higher concentrations, the addition of a background concentration has a negligible effect.

Figure 5. Comparison of average concentrations in $\mu \mathrm{g} / \mathrm{m}^{3}$ in the atmosphere in 1995 and 2005 derived from Equation (5) and the MSCE-POP model, respectively, considering background concentrations from extracontinental sources.

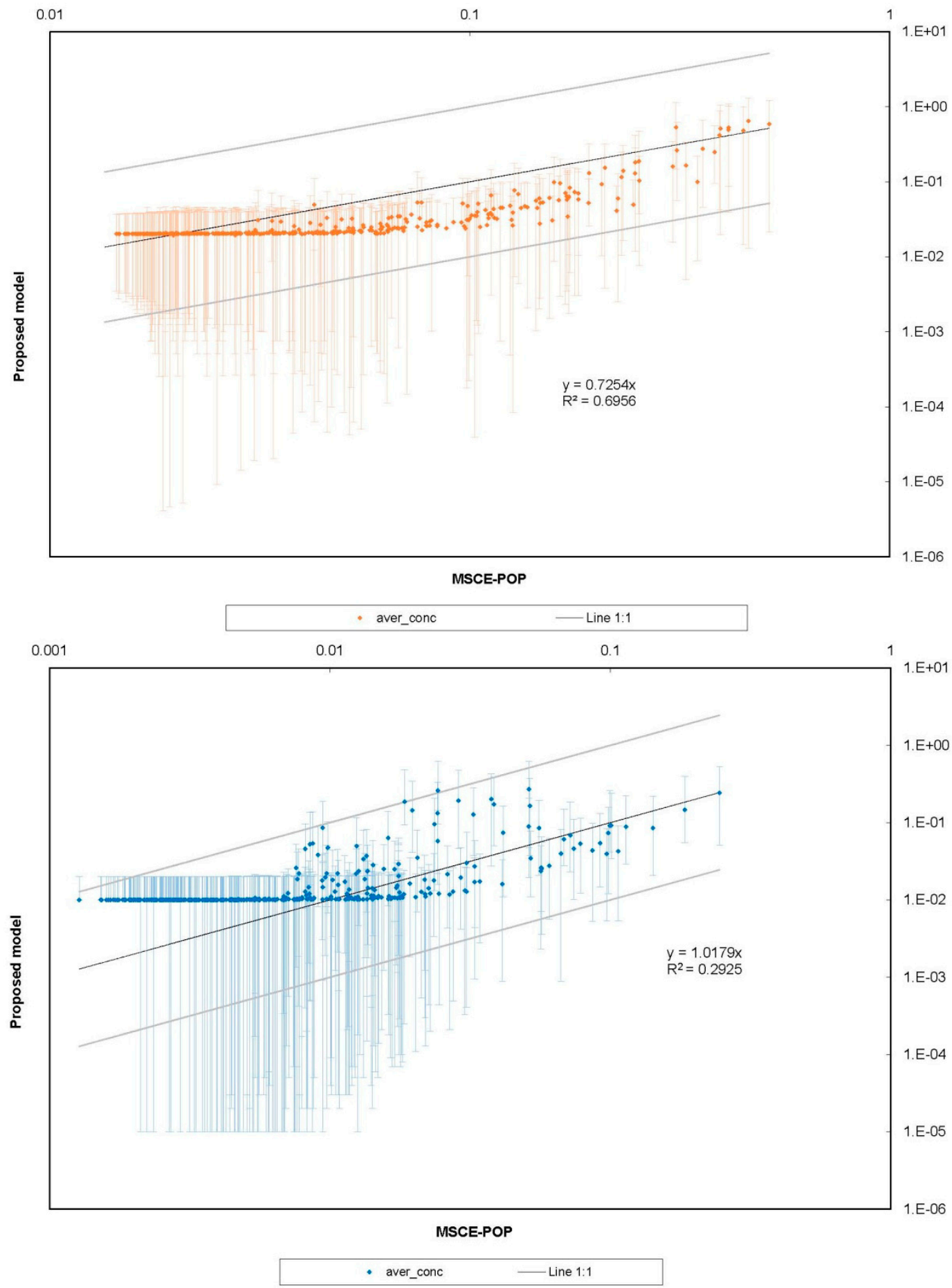


Figure 5 shows how adding the background of $20 \mathrm{pg} / \mathrm{m}^{3}$ for 1995 and $10 \mathrm{pg} / \mathrm{m}^{3}$ for 2005 to concentrations predicted with Equation (5) allows bringing the predictions to the same range of observed concentrations, consistently with the MSCE-POP model. These background concentrations are about half an order of magnitude lower than those used by other authors [49] in the computation of lindane concentrations at the European scale.

Despite this better correspondence, the scatter diagrams of Figure 5 still highlight a discrepancy between the two models, which takes the form of a trend in underestimation at intermediate values and some discrepancies between the spatial locations of the highest concentrations. The former may depend on the different resolutions of the MSCE-POP model and the grid on which Equation (5) is solved. A coarser resolution implies higher numerical dispersion (see, e.g., [50]), determining lower peaks and a higher spread of intermediate concentrations. The averaging of a model at a finer resolution within a coarser resolution, as done for the results of Equation (5) within cells of the MSCE-POP model, also implies that intermediate concentrations are spread wider. For the case of the discrepancies observed in the spatial distribution of the highest concentrations, the differences between the two models are more evident for the year 2005. In this case, the reason might be the difference of the spatial distribution of emissions in both models, as can be detected from maps of emissions reported from the MSCE-POP model [41] when compared to those resulting from the proportional distribution of emissions according to population density used for the computation of concentrations by using Equation (5).

\section{Conclusions}

The proposed Equation (5) allows reproducing the spatial distribution of $\gamma-\mathrm{HCH}$ concentrations estimated through the MSCE-POP model with reasonable accuracy. Discrepancies between the two models can be explained through the effects of concentrations from remote sources, which, in turn, may be accounted for using Equation (7) and through the different spatial resolutions adopted. Therefore, within the limits of accuracy highlighted in the present research, PECs of contaminants in the atmosphere can be estimated for Europe using such a simple and fast model, leading to results similar to the ones of a much more complex model, such as MSCE-POP. Although simple models are often selected in order to limit data gathering and computational burdens, their advantage is not just in computational costs: the use of a simple equation to test different assumptions on emission intensity and spatial patterns favors the transparency of assessments at the screening level. The practical application of as simple a model as Equation (4) or Equation (5) is in checking the compatibility between observed concentrations at different locations over a region, and estimated emissions. We have shown, for instance, that general trends of $\gamma-\mathrm{HCH}$ in the European atmosphere can be explained from reported emissions both from Europe and from remote sources and that the latter cannot be ignored when estimating concentrations near background values. The use of simple models does not substitute the use of more sophisticated ones, which remain necessary tools for more detailed predictions, e.g., situations where a specific physico-chemical process or a single contamination episode are of interest. On the other hand, developing simple GIS-based models continues to appear as a very practical alternative for the spatial characterization of pollutants whose scientific understanding is affected by large uncertainties, when a few fundamental parameters (essentially, the spatial 
distribution and intensity of emissions) drive, in the first instance, the spatial distribution of concentrations.

\section{Acknowledgments}

This research was partly funded by the European Commission through NoMiracle an Integrated Project (IP) to Call FP6-2003-Global-2 (http://nomiracle.jrc.ec.europa.eu/default.aspx). We gratefully acknowledge colleagues from EMEP MSCE-POP, Alexey. Gusev and Viktor Shalatov, who provided data and discussion on the case study of $\gamma-\mathrm{HCH}$, and Jean-Philippe Aurambout from JRC, who helped with the programming of GIS calculations. Carolina. Alamo at JRC helped with collecting monitoring data on $\gamma-\mathrm{HCH}$ published in the literature.

\section{Author Contributions}

Alberto Pistocchi and Pilar Vizcaino conceived and designed the experiments; Pilar Vizcaino. performed the experiments; Pilar Vizcaino analyzed the data; Pilar Vizcaino and Alberto Pistocchi contributed reagents/materials/analysis tools; Pilar Vizcaino and Alberto Pistocchi wrote the paper.

\section{Conflicts of Interest}

The authors declare no conflict of interest.

\section{References}

1. Gusev, A.; Mantseva, E.; Shatalov, V.; Strukov, B. Regional Multicompartment Model MSCE-POP; EMEP/MSC-E Technical Report 05/2005; Available online: http://www.emep.int/ (accessed on 30 October 2012).

2. European Union System for the Evaluation of Substances 2.0 (EUSES 2.0). Available online: http://ecb.jrc.it (accessed on 5 May 2014).

3. Van de Meent, D. SIMPLEBOX-A Generic Multimedia Fate Evaluation Model Report No. 672720001; National Institute of Public Health and the Environment (RIVM): Bilthoven, The Netherlands, 1993.

4. Roemer, M.; Baart, A.; Libre, J.M. ADEPT: Development of an Atmospheric Deposition and Transport Model for Risk Assessment; TNO Report B\&O-A R 2005-208; TNO: Apeldoorn, The Netherlands, 2005.

5. Pistocchi, A. A GIS-based approach for modeling the fate and transport of pollutants in Europe. Environ. Sci. Technol. 2008, 42, 3640-3647.

6. Pistocchi, A.; Zulian, G.; Vizcaino, P.; Marinov, D. Multimedia Assessment of Pollutant Pathways in the Environment, European Scale Model (MAPPEEUROPE); EUR 24256 EN; Office for Official Publications of the European Communities: Luxembourg, 2010.

7. Pistocchi, A. GIS Based Chemical Fate Modeling: Principles and Applications; John Wiley \& Sons: Hoboken, NJ, USA, 2013; p. 504. 
8. Pistocchi, A.; Vizcaino Martinez, M.P.; Pennington, D.W. Analysis of Landscape and Climate Parameters for Continental Scale Assessment of the Fate of Pollutants; EUR 22624 EN; Office for Official Publications of the European Communities: Luxembourg, 2006.

9. Pistocchi, A.; Galmarini, S. Evaluation of a simple spatially explicit model of atmospheric transport of pollutants in Europe. Environ. Model Assess. 2010, 15, 37-51.

10. Li, Y.F. Global technical hexachlorocyclohexane usage and its contamination consequences in the environment: From 1948 to 1997. Sci. Total Environ. 1999, 232, 121-158.

11. Stockholm Convention on Persistent Organic Pollutants (POPs). Available online: http://chm.pops.int/ (accessed on 9 September 2013).

12. UNECE. Convention on Long-Range Transboundary Air Pollution. Available online: http://www.unece.org/env/lrtap/pops_h1.htm (accessed on 23 November 2013).

13. Commission Decision of 20 December 2000 Concerning the Non-Inclusion of Lindane in Annex I to Council Directive 91/414/EEC and the Withdrawal of Authorisations for Plant-Protection Products Containing this Active Substance. Available online: http://www.scc-gmbh.de/ New_Regulations_Approvals_Agrochemicals/84_1_lindane_2000_801_EC_EN.pdf (accessed on 11 February 2014).

14. Breivik, K.; Alcok, R.; Li, Y.F.; Bailey, R.E.; Fiedler, H.; Pacyna, J.M. Primary sources of selected POPs: Regional and global scale emission inventories. Environ. Pollut. 2004, 128, 3-16.

15. Li, Y.F. Emission Inventories of g-HCH for North America during 2000 and 2002; Internal Report; Meteorological Service of Canada: Toronto, ON, Canada, 2004.

16. Li, Y.F.; Trevor Scholtz, M.; van Heyst, B.J. Global gridded emission inventories of $\beta$-hexachlorocyclohexane. Environ. Sci. Technol. 2003, 37, 3493-3498.

17. Van Jaarsveld, J.A.; van Pul, W.A.J.; de Leeuw, F.A.A.M. Modelling transport and deposition of persistent organic pollutants. Atmos. Environ. 1997, 31, 1011-1024.

18. Wania, F.; Mackay, D.; Li, Y.; Bidleman, F.; Strand, A. Global chemical fate of $\alpha$-Hexaclorocyclohexane. 1. Evaluation of a global distribution model. Environ. Toxicol. Chem. 1999, 18, 1390-1399.

19. Li, Y.F.; MacDonald, R. Sources and pathways of selected organochlorine pesticides to the Arctic and the effect of pathway divergence on $\mathrm{HCH}$ trends in biota: A review. Sci. Total Environ. 2005, 342, 87-106.

20. Tuduri, L.; Harne, T.; Blanchard, P.; Li, Y.-F.; Poissant, L.; Waite, D.T.; Murphy, C.; Belze, W. A review of currently used pesticides (CUPs) in Canadian air and precipitation: Part 1: Lindane and endosulfans. Atmos. Environ. 2006, 40, 1563-1578.

21. Jaward, F.J.; Farrar, N.; Harner, T.; Sweetman, A.; Jones, K. Passive air sampling of PCBs, PBDEs, and organochlorine pesticides across Europe. Environ. Sci. Technol. 2004, 38, 34-41.

22. Van Drooge, B.; Grimalt, J.; Camarero, L.; Catalán, J.; Stuchlik, E.; Torres García, C.J. Atmospheric semivolatile organochlorine compounds in European high-mountain areas (central Pyrenees and high Tatras). Environ. Sci. Technol. 2004, 38, 3525-3532.

23. EMEP Measurement Data Online. Available online: http://www.nilu.no/projects/ccc/emepdata.html (accessed on 20 April 2011).

24. Kylin, H.; Sjödin, A. Accumulation of airborne hexachlorocyclohexanes and DDT in pine needles. Environ. Sci. Technol. 2003, 37, 2350-2355. 
25. Wenzel, K.D.; Manz, M.; Hubert, A.; Schuurmann, G. Fate of POP's (DDX, HCHs, PCBs) in upper soil layers of pine forests. Sci. Total Environ. 2002, 286, 143-154.

26. Lakaschus, S.; Weber, K.; Wania, F.; Bruhn, R.; Schrems, O. The air-sea equilibrium and time trend of hexachlorocyclohexanes in the Atlantic Ocean between the Arctic and Antarctica. Environ. Sci. Technol. 2002, 36, 138-145.

27. Estellano V.H.; Pozo K.; Harner T.; Corsolini S.; Focardi, S. Using PUF disk passive samplers to simultaneously measure air concentrations of persistent organic pollutants (POPs) across the Tuscany Region, Italy. Atmos. Pollut. Res. 2012, 3, 88-94.

28. Holoubek, I.; Klanova, J.; Jarkovsky, J.; Kohoutek, J. Assessment of the Central European trends in the background levels of persistent organic pollutants based on the results of the long-term integrated monitoring in Kosetice observatory, Czech Republic. Part I. Ambient air and wet deposition 1988-2005. J. Environ. Monit. 2007, 9, 557-563.

29. Scheyer, A.; Graeff, C.; Morville, S.; Mirabel, P.; Millet, M. Analysis of some organochlorine pesticides in an urban atmosphere (Strasbourg, east of France). Chemosphere 2005, 58, 1517-1524.

30. Bartnicki, J.; Gusev, A.; Berg, T.; Fagerlil, H. Atmospheric Supply of Nitrogen, Lead, Cadmium, Mercury and Lindane to the Baltic Sea in 2002; EMEP/MSC-W Technical Report 3/2004. Available online: http://emep.int/publ/helcom/2004/index.html (accessed on 15 September 2013).

31. Buijsman, E.; van Pul, W.A.J. Long-term measurements of $\gamma-\mathrm{HCH}$ in precipitation in The Netherlands. Water Air Soil Pollut. 2003, 150, 59-71.

32. IHPA. A global overview of residue management, formulation and disposal. In The Legacy of Lindane HCH Isomer Production; Available online: http:/www.ihpa.info/docs/library/reports/ Lindane\%20AnnexesDEF20JAN06.pdf (accessed on 2 November 2013).

33. Pacyna, J.M. Final Report for Project POPCYCLING-Baltic EU DGXIII; Environment and Climate Program ENV4-CT96-0214; NILU: Kjelier, Norway, 1999.

34. Harner, T.; Bidleman. T.F. Measurement of octanol- air partition coefficient for polycyclic aromatic hydrocarbons and polychlorinated naphthalenes. J. Chem. Eng. Data 1998, 43, 40-46.

35. Saleh, F.Y.; Dickson, K.L.; Rodgers, J.H. Fate of lindane in the aquatic environment: Rate constants of physical and chemical processes. Environ. Toxicol. Chem. 1982, 1, 289-297.

36. Mackay, D.; Shiu, W.-Y.; Ma, K.-C. Illustrated Handbook of Physical-Chemical Properties and Environmental Fate of Organic Chemicals; CRC Press: BocaRaton, FL, USA, 1997.

37. Brubaker, W.W.; Hites. R.A. OH reaction kinetics of gase-phase $\alpha$ - and $\gamma$ - hexachlorocyclohexane and hexachlorobenzene. Environ. Sci. Technol. 1998, 32, 766-769.

38. CEIP. Officially Reported Emission Data. Available online: http://www.ceip.at/ webdab_emepdatabase/reported_emissiondata (accessed on 21 August 2014).

39. EEA. European Union Emission Inventory Report 1990-2011 under the UNECE Convention on Long-Range Transboundary Air Pollution (LRTAP); EEA Technical Report No 10/2013; Available online: http://www.eea.europa.eu/publications/eu-emission-inventory-report-lrtap (accessed on 21 August 2014).

40. Gusev, A.; Mantseva, E.; Shatalov, V.; Rozovskaya, O.; Vulykh, N.; Breivik, K.; Halse, A.K. Persistent Organic Pollutants in the Environment; EMEP/MSC-E Technical Report 03/2007; Available online: http://www.emep.int/ (accessed on 7 December 2010). 
41. Breivik, K.; Wania, F. Evaluating a model of the historical behavior of two hexachlorocyclohexanes in the Baltic Sea. Environ. Sci. Technol. 2002, 36, 1014-1023.

42. Vizcaino, P.; Pistocchi, A. A GIS model-based assessment of the environmental distribution of $\gamma$-Hexachlorocyclohexane in European soils and waters. Environ. Pollut. 2010, 158, 3017-3027.

43. Pistocchi, A.; Bouraoui, F.; Bittelli. M. A simplified parameterization of the monthly topsoil water budget. Water Resour. Res. 2008, doi:10.1029/2007WR006603.

44. Gusev, V. MSC-E Meteorological Synthesizing Centre-East, Moscow, Russia. Personal communication, 2010.

45. Gusev, A.; Li, Y.-F.; Mantseva, E.; Shatalov, V.; Rozovskaya, O.; Vulykh, N. Evaluation of $B[a] P$ and $\gamma-H C H$ Transport from European and North American Emission Sources and Assessment of Deposition to the OSPAR Region; EMEP/MSC-E Technical Report 12/2005; Available online: http://www.msceast.org/reports/12_2005.pdf (accessed on 7 December 2010).

46. Shen, L.; Wania, F.; Ying, L.; Teixeira, C.; Muir, D.; Bidleman, T. Hexachlorocyclohexanes in the North American atmosphere. Environ. Sci. Technol. 2004, 38, 965-975.

47. UNEP. Risk management evaluation on Lindane. In Report of the Persistent Organic Pollutants Review Committee on the work of its Third Meeting; Available online: http://www.pops.int/ documents/meetings/poprc/POPRC3/POPRC3_Report_e/POPRC3_Report_add4_e.pdf (accessed on 1 February 2014).

48. CEC. North American Regional Action Plan on Lindane and Other Hexachlorocyclohexane Isomers; Final Report; Commission for Environmental Cooperation: Montreal, QC, Canada, 2013.

49. Prevedouros, K.; MacLeod, M.; Jones, K.C.; Sweetmana, A. Modelling the fate of persistent organic pollutants in Europe: Parameterization of a gridded distribution model. Environ. Pollut. 2004, 128, 251-261.

50. Abbot, M.B.; Minns, A.W. Computational Hydraulics, 2nd ed.; Ashgate: Brookfield, VT, USA, $1998 ;$ p. 557.

(C) 2014 by the authors; licensee MDPI, Basel, Switzerland. This article is an open access article distributed under the terms and conditions of the Creative Commons Attribution license (http://creativecommons.org/licenses/by/4.0/). 